\title{
STRATEGI PENGUATAN PERENCANAAN DAN PENGANGGARAN PADA SUBSEKTOR KELAUTAN DAN PERIKANAN DI KABUPATEN KEPULAUAN ANAMBAS
}

\section{Strengthening Strategies of Planning and Budgeting on Marine and Fishery Subsector at Anambas Archipelago Regency}

\section{Feby Kurnia1, Ma'mun Sarma², Dwi Rachmina ${ }^{3}$}

\author{
1 Staff Kantor Camat Siantan Tengah Kabupaten Kepulauan Anambas, Provinsi Kepulauan Riau. E-mail : \\ febykurnia,mail@gmail.com \\ 2 Staff Pengajar Departemen Manajemen, Fakultas Ekonomi dan Manajemen IPB. E-mail : \\ mamun_sarma@yahoo.com \\ ${ }^{3}$ Staff Pengajar Departemen Agribisnis, Fakultas Ekonomi dan Manajemen IPB. E-mail : \\ dwirachmina@gmail.com
}

\begin{abstract}
The financial condition of the region that continues to experience of fluctuations and the allocation of development funds in the marine and fishery sub-sector which tend to decrease every year become problems that often arise. It requires local governments to be able to determine the right strategy in order to produce appropriate planning and budgeting development that are suitable with the potential of the marine and fisheries sub-sector. The pusrposes of this research are to analyze the consistency of planning and budgeting formulation, to analyze the implementation of planning and budgeting, and to formulate priority strategies that needed in an effort to strengthen planning and budgeting in marine and fisheries sub-sector in Anambas Achipelago Regency. The method used is using PBCM (Planning and Budgeting Consistency Matrix) analysis, perception analysis using Likert scale, SWOT analysis and QSPM method. The result of the research shows that there are inconsistencies in planning and budgeting as well as the level of implementation of planning and budgeting that are good but still need improvement on human resources competency component. The main priority strategy chosen is the improvement of the quality of the planning apparatus held by the local government through coordination and cooperation between the Governments (local and central) with University.

Keywords: PBCM, Perception Analysis, Planing and Budgeting Implementation, Strengthening Srategies
\end{abstract}

\section{ABSTRAK}

Kondisi keuangan daerah yang terus mengalami fluktuasi serta alokasi dana pembangunan pada subsektor kelautan dan perikanan yang cenderung mengalami penurunan setiap tahunnya menjadi permasalahan yang kerap timbul. Hal tersebut mengharuskan pemerintah daerah mampu menentukan strategi yang tepat agar dapat menghasilkan perencanaan dan penganggaran pembangunan yang tepat sesuai dengan potensi yang dimiliki. Penelitian ini bertujuan untuk menganalisis konsistensi perumusan perencanaan dan penganggaran, menganalisis implementasi perencanaan dan penganggaran serta merumuskan strategi yang perlu diprioritaskan dalam upaya menguatkan perencanaan dan penganggaran pada subsektor kelautan dan perikanan di Kabupaten Kepulauan Anambas. Metode yang digunakan adalah menggunakan analisis Matrik Konsistensi Perencanaan dan Penganggaran (MKPP), analisis kuesioner menggunakan skala likert, analisis SWOT dan metode QSPM. Hasil penelitian menunjukkan masih terdapat inkonsistensi pada perencanaan dan penganggaran serta tingkat implementasi perencanaan dan penganggaran tergolong baik namun masih perlu perbaikan pada komponen kompetensi SDM. Strategi prioritas utama yang dipilih adalah peningkatan kualitas aparatur perencanaan yang dimiliki oleh pemerintah daerah melalui koordinasi dan kerja sama antara Pemerintah (daerah dan pusat) dengan institusi perguruan tinggi.

Kata Kunci : Analisis Persepsi, Implementasi Perencanaan dan Penganggaran, MKPP, Strategi penguatan 


\section{PENDAHULUAN}

Pengelolaan keuangan daerah terdiri dari pendapatan serta belanja daerah yang terangkum didalam rencana keuangan tahunan pemerintah daerah yang disetujui oleh Dewan Perwakilan Rakyat Daerah (DPRD) dalam wujud Anggaran Pendapatan dan Belanja Daerah (APBD). Melalui APDB dijabarkan secara terperinci kebijakan perencanaan dan penganggaran keuangan yang akan dilaksanakan oleh Pemerintah Daerah untuk masa tertentu, yaitu satu tahun anggaran (Adisasmita 2011). Permasalahan yang kerap ditemukan dalam perencanaan dan penganggaran selain tidak berimbangnya antara belanja rutin dan pembangunan, adalah ketidaktepatan di dalam mengalokasikan anggaran itu sendiri terhadap sektorsektor yang seharusnya mendapat prioritas. Ketidaktepatan didalam alokasi anggaran akan menyebabkan inefesiensi, sehingga tujuan pembangunan yang diharapkan tidak tercapai.

Permasalahan tersebut juga ditemukan pada perencanaan dan penganggaran pada subsektor kelautan dan perikanan di Kabupaten Kepulauan Anambas. Kabupaten Kepulauan Anambas merupakan salah satu kabupaten yang ada di Provinsi Kepulauan Riau. Kabupaten Kepulauan Anambas memiliki luas wilayah yang 98 persennya merupakan lautan. Sektor potensial yang dimiliki oleh daerah yaitu dengan kontribusi PDRB tertinggi 22,45 persen adalah sektor kelautan dan perikanan. Sektor tersebut cenderung hanya mendapatkan alokasi anggaran yang kecil dalam APBD yaitu sebesar 1,57 persen pada tahun 2014. Alokasi tersebut bahkan mengalami penurunan pada tahun berikutnya menjadi 1,47 persen (BPS KKA 2016). Tentunya hal ini bertolak belakang dengan visi serta program prioritas daerah yaitu mengkedepankan potensi kelautan dan perikanan dalam program prioritas pembangunan daerah. Kondisi tersebut ditambah dengan penerimaan daerah yang masih cenderung mengalami fluktuasi dan bahkan menurun setiap tahunnya. Hal tersebut mendorong pemerintah untuk lebih jeli dalam mengalokasikan anggarannya yang semakin terbatas agar tetap dapat menghasilkan kinerja pembangunan yang optimal.

Sehubungan dengan permasalahan yang telah dikemukakan tersebut, maka menjadi penting untuk dikaji bagaimana pengelolaan keuangan daerah, khususnya pada pelaksanaan perencanaan dan penganggaran pada subsektor kelautan dan perikanan di Kabupaten Kepulauan Anambas. Hal tersebut juga sebagai langkah mewujudkan visi dan misi daerah dengan mengedepankan pembangunan potensi maritim yang dimiliki khususnya subsektor kelautan dan perikanan. Langkah yang dilakukan dimulai dari melihat konsistensi perencanaan dan penganggaran serta apa saja yang menjadi kelemahan, kekuatan, ancaman serta peluang yang dihadapi dalam pelaksanaan pembangunan subsektor kelautan dan perikanan tersebut. Data tersebut lalu digunakan untuk merumuskan strategi penguatan perencanaan penganggaran pada subsektor kelautan dan perikanan di Kabupaten Kepulauan Anambas.

Tujuan dari penelitian ini adalah: (1) Menganalisis konsistensi perumusan perencanaan penganggaran pada subsektor kelautan dan perikanan di Kabupaten Kepulauan Anambas; (2) Menganalisis implementasi perencanaan penganggaran pada subsektor kelautan dan perikanan di Kabupaten Kepulauan Anambas; dan (3) Menyusun dan merumuskan strategi yang tepat dalam penguatan perencanaan penganggaran pada subsektor kelautan dan perikanan di Kabupaten Kepulauan Anambas. 


\section{METODOLOGI}

Penelitian dilaksanakan di Kabupaten Kepulauan Anambas Provinsi Kepulauan Riau tepatnya pada Dinas Perikanan, Pertanian dan Pangan. Dinas Perikanan, Pertanian dan Pangan merupakan organisasi perangkat daerah yang telah ditentukan sebagai koordinator sektor perikanan, pertanian dan pangan di Kabupaten Kepulauan Anambas. Jenis data yang digunakan dalam penelitian ini adalah seluruh data perencanaan dan penganggaran khususnya subsektor kelautan dan perikanan yang terdiri dari data primer dan data sekunder. Data primer diperoleh dengan cara observasi langsung, wawancara dan penyebaran kuesioner. Sedangkan untuk mendapatkan data sekunder berasal dari studi pustaka dan kajian terhadap literatur terkait. Total Responden berjumlah 15 orang yang terdiri dari pejabat dan aparatur fungsional yang menangani perencanaan dan penganggaran yang berhubungan dengan sektor kelautan dan perikanan di Kabupaten Kepulauan Anambas. Aparatur tersebut terdiri dari aparatur perencanaan dana penganggaran yang berada pada Dinas perikanan, pertanian dan pangan, Badan Penelitian Pengembangan Perencanaan Daerah (BALITBANGPEDA), Badan Keuangan Daerah (BKD), Inspektorat, Dinas Pekerjaan Umum. Data sekunder diperoleh dari Dokumen perencanaan daerah dari RPJMD, RKPD, KUA-PPAS dan DPA SKPD tahun 20142017, dokumen serta regulasi terkait dan relevan dalam penelitian ini. Alat analisis yang digunakan sesuai dengan urutan tujuan dalam penelitian ini adalah: (1) Matriks konsistensi perencanaan dan penganggaran (MKPP), (2) analisis persepsi menggunakan skala likert, (3) anaslis SWOT serta (4) analisis Quantitative Strategic Planning Matrix (QSPM).

Matriks konsistensi perencanaan dan penganggaran (MKKP) dilakukan untuk mengetahui tingkat konsistensi perencanaan dan penganggaran yang dilakukan (Bastian 2006). MKPP dilakukan dengan cara membandingkan konsistensi program, kegiatan serta anggaran yang diakomodir pada setiap tahapan perencanaan dari RPJM hingga DPA. Skala likert digunakan untuk menganalisis persepsi responden terhadap implementasi perencanaan dan penganggaran yang meliputi komponen kompetensi SDM, sistem administrasi perencanaan dan penganggaran, kesesuian perencanaan dan penganggaran, penghargaan serta sanksi. Komponen tersebut merupakan kondisi yang terjadi pada lingkup internal pemerintah daerah selaku eksekutif.

Analisis SWOT perlu dilakukan untuk menetapkan alternatif strategi yang paling tepat dalam rangka penguatan perencanaan dan penganggaran pada subsektor kelautan dan perikanan di Pemerintah Kabupaten Kepulauan Anambas. Faktor penting yang menjadi kunci dalam pemilihan strategi penguatan perencanaan dan penganggaran tersebut terdiri dari faktor kunci internal (IFE) dan faktor kunci eksternal (EFE). Penentuan bobot dilakukan dengan mengajukan identifikasi faktor internal dan eksternal kepada stakeholder dengan menggunakan metode paired comparison (Kinnear dan Taylor, 1991). Metode ini digunakan untuk memberikan penilaian terhadap bobot di setiap faktor-faktor internal dan eksternal.

Analisis QSPM bertujuan untuk menetapkan prioritas strategi terbaik yang paling layak untuk diimplementasikan sesuai dengan arah dan kebijakan Pemerintah Kabupaten Kepulauan Anambas dalam hal pengelolaan keuangan daerah. Analisis QSPM menggunakan skor daya tarik atau Atrractiveness Scores (AS) dengan Nilai Daya Tarik adalah $1=$ tidak menarik, $2=$ agak menarik, $3=$ cukup menarik, $4=$ sangat menarik.Penentuan prioritas strategi terbaik dilakukan dengan cara menentukan rating atau tingkat 
ketertarikan relatif dari strategi-strategi yang telah dipilih. Nilai Total Attractiveness Scores (TAS) tertinggi menandakan strategi yang paling layak untuk diimplementasikan dengan memperhatikan seluruh faktor internal dan eksternal (David dan David 2015).

\section{HASIL DAN PEMBAHASAN}

\section{Analisis konsistensi perumusan perencanaan penganggaran pada subsektor kelautan dan perikanan di Kabupaten Kepulauan Anambas}

Kondisi keuangan daerah yang dituangkan dalam APDB cenderung mengalami penurunan setiap tahunnya. Hal tersebut tentunya akan mempengaruhi daerah dalam melaksanakan pembangunan daerah, yang tentunya program pembangunan yang dapat dilaksanakan daerah semakin terbatas. Untuk mengetahui hal tersebut, maka dilakukan analisis konsistensi dari sisi anggaran. Anggaran merupakan hal krusial bagi pembangunan daerah. Perencanaan dan anggaran merupakan suatu kesinambungan yang tidak dapat dipisahkan. Tingkat konsistensi anggaran dapat dilihat melalui deviasi anggaran yang terjadi. Pada kesempatan ini peneliti akan melakukan penghitungan deviasi anggaran yang terdapat pada RKPD dengan anggaran yang terdapat pada APBD yang tertuang melalui DPA SKPD. Kondisi deviasi anggaran pada subsektor kelautan dan perikanan di Kabupaten Kepulauan Anambas dapat dilihat pada Tabel 1.

Tabel 1 Deviasi anggaran pada subsektor kelautan dan perikanan Tahun 2014-2017

\begin{tabular}{rcrrrr}
\hline \multirow{2}{*}{ No } & Tahun & \multicolumn{1}{c}{ RKPD } & \multicolumn{2}{c}{ APBD } & \multicolumn{2}{c}{ Deviasi anggaran } \\
\cline { 3 - 6 } & Penganggaran & \multicolumn{1}{c}{$(\mathrm{Rp})$} & \multicolumn{1}{c}{$(\mathrm{Rp})$} & \multicolumn{1}{c}{$(\mathrm{Rp})$} & \multicolumn{1}{c}{$\%$} \\
\hline 1 & 2014 & 19.141 .349 .931 & 17.934 .666 .045 & 1.206 .683 .886 & $-6,30$ \\
2 & 2015 & 18.662 .968 .099 & 16.656 .448 .915 & 2.006 .519 .184 & $-10,75$ \\
3 & 2016 & 11.711 .876 .621 & 11.035 .364 .621 & 676.512 .000 & $-5,78$ \\
4 & 2017 & 6.060 .749 .574 & 9.070 .768 .000 & 3.010 .018 .426 & 49,66 \\
\hline
\end{tabular}

Deviasi anggaran menunjukkan bahwa masih kurangnya kemampuan untuk melakukan proyeksi antara penerimaan dan belanja daerah. Dalam manajemen keuangan daerah, hal tersebut disinyalkan melalui defisit anggaran dikarenakan target penerimaan tidak sesuai dengan rencana. Ketidaksesuaian tersebut dapat berupa tidak tercapainya target penerimaan maupun penerimaan yang melebihi target yang telah ditetapkan. Deviasi anggaran tentunya akan berdampak kepada program dan kegiatan yang telah direncanakan oleh pemerintah daerah sehingga diperlukan penyesuaian kembali dokumen perencanaan. Berdasarkan Tabel 1, menunjukkan bahwa pada tahun 2014 hingga 2017 selalu mengalami deviasi anggaran. Pada tahun 2014 terjadi deviasi sebesar 6,3 persen yang mengakibatkan terjadinya defisit anggaran daerah. Begitu pula yang terjadi pada tahun 2015 dan tahun 2016 yang juga mengalami defisit anggaran. Tidak hanya itu, deviasi anggaran yang terjadi juga diiringi dengan penurunan nominal anggaran yang dialokasikan kepada subsektor kelautan dan perikanan. Pada tahun 2017 terjadi deviasi yang positif, yaitu terdapat peningkatan anggaran sebesar 49,66 persen dari total anggaran yang pada mulanya dianggarkan di RKPD.

Deviasi anggaran yang selalu terjadi dikarenakan karena jumlah penerimaan daerah yang selalu mengalami perubahan, khususnya pada porsi dana perimbangan berupa dana bagi hasil minyak dan gas. Fluktuasi harga minyak yang cenderung mengalami penurunan 
tentunya akan berdampak kepada penerimaan daerah oleh pusat yang berasal dari sektor tersebut. Namun pada tahun 2017, kelebihan penerimaan yang diperoleh daerah merupakan hasil dari salah satu langkah daerah untuk mengantisipasi terjadinya defisit anggaran. Berdasarkan pengalaman yang terjadi pada tahun-tahun sebelumnya, membuat daerah untuk tidak menggunakan taget penerimaan maksimal dalam menentukana proyeksi penerimaan pada RKPD. Sehingga kelebihan penerimaan yang diperoleh dalam tahun berjalan dapat dialokasikan melalui mekanisme APBD-P.

\section{Konsistensi Perencanaan Kegiatan}

Kondisi konsistensi perencanaan kegiatan pada subsektor kelautan dan perikanan. Hampir setiap tahunnya selalu terjadi inkonsistensi kecuali pada tahun 2015. Inkonsistensi yang terjadi pada tahun 2014 dikarenakan pada proses penentuan Kebijakan Umum Anggaran (KUA) terjadi proses politis yang alot dan dianggap 7 kegiatan yang telah disepakati pada Rencana Kerja Pemerintah Daerah (RKPD) tidak dapat diakomodir pada tahun tersebut, sehingga dilakukan penyusunan ulang dan terbentuklah 5 kegiatan baru yang dapat direalisasikan pada Dokumen Pelaksanaan Anggaran (DPA). Namun pada tahun 2015, keseluruhan kegiatan dapat terakomodir dan terlaksanan sepenuhnya pada tahun berjalan. Pada tahun 2016 terjadi inkonsistensi yang disebabkan perencanaan yang mematok anggaran kegiatan minimal untuk menghindari terjadinya defisit anggaran, namun pada tahun berjalan dapat terakomodir melalui mekanisme APBD-P. Hal yang sama juga terjadi pada tahun 2017. Walaupun daerah melakukan tersebut untuk menghindari terjadinya defisit anggaran, tetapi hal tersebut menandakan bahwa daerah masih belum dapat menentukan perencanaan dan penganggaran yang baik dikarenakan masih sangat terpengaruh oleh fluktuasi alokasi dana transfer pusat untuk daerah. Konsistensi perencanaan kegiatan pada subsektor kelautan dan perikanan secara keseluruhan disajikan pada Tabel 2.

Tabel 2 Matrik konsistensi perencanaan kegiatan subsektor kelautan dan perikanan di Kabupaten Kepulauan Anambas Tahun 2014-2017

\begin{tabular}{llcccc}
\hline \multirow{2}{*}{ No } & \multicolumn{1}{c}{ Status Kegiatan } & \multicolumn{4}{c}{ Dokumen perencanaan (tahun) } \\
\cline { 3 - 6 } & & 2014 & 2015 & 2016 & 2017 \\
\hline 1 & Konsisten & 11 & 15 & 7 & 2 \\
2 & Tidak konsisten & & & & \\
& a. Tidak terakomodir & 7 & - & 1 & - \\
& b. Muncul kegiatan baru & 5 & - & 4 & 5 \\
\hline & Jumlah & 23 & 15 & 12 & 7 \\
\hline & Tingkat Konsistensi (\%) & 47,83 & 100,00 & 58,33 & 28,57 \\
\hline
\end{tabular}

Implementasi Perencanaan dan Penganggaran Pada Subsektor Kelautan dan Perikanan di Kabupaten Kepulauan Anambas

Pengukuran implementasi perencanaan dan penganggaran ini dianalisis dengan menggunakan skala likert yang berhubungan dengan perencanaan dan penganggaran di subsektor kelautan dan perikanan. Pada analisis ini terdapat lima komponen penilaian yang berpengaruh terhadap perencanaan dan penganggaran. Kelima komponen penilaian tersebut meliputi kompetensi SDM perencanaan penganggaran, sistem administrasi perencanaan dan penganggaran, 
kesesuaian perencanaan penganggaran, penghargaan (reward) dan sanksi (punishment). Semakin tinggi skor hasil yang diperoleh maka semakin baik implementasi perencanaan dan penganggaran yang dihasilkan. Dalam pengukuran yang dilakukan telah ditentukan bahwa setiap nilai skor tertinggi setiap pertanyaan adalah 4 sehingga nilai maksimal yang akan diperoleh adalah $4 \times 27 \times 15$ responden $=$ 1620, dan nilai terendah adalah 1 sehingga skor yang akan diperoleh adalah 1 x $27 \mathrm{x}$ $15=405$, Hasil dari seluruh komponen penilaian disajikan pada Tabel 3.

Tabel 3 Persepsi responden terhadap implementasi perencanaan dan penganggaran pada subsektor kelautan dan perikanan di Kabupaten Kepulauan Anambas

\begin{tabular}{clccc}
\hline \multirow{2}{*}{ No } & \multicolumn{1}{c}{ Komponen Penilaian } & $\begin{array}{c}\text { Skor } \\
\text { Maksimal }\end{array}$ & $\begin{array}{c}\text { Skor } \\
\text { Total }\end{array}$ & Kategori \\
\hline 1 & Kompetensi SDM perencanaan dan penganggaran & 600 & 430 & Sedang \\
2 & Sistem Administrasi Perencanaan dan & 240 & 191 & Tinggi \\
& penganggaran & 420 & 328 & Tinggi \\
3 & Kesesuaian Perencanaan Penganggaran & 180 & 144 & Tinggi \\
4 & Penghargaan (reward) & 180 & 137 & Tinggi \\
\hline 5 & Sanksi (punishment) & 1620 & 1230 & Tinggi \\
\hline
\end{tabular}

\section{Komponen Kompetensi SDM Perencanaan dan Penganggaran}

Berdasarkan pengukuran yang dilakukan, ditemukan bahwa indikator yang ada pada komponen kompetensi SDM 5 dari 10 indikator yang ada berada pada kategori sedang. Adapun yang menjadi kelemahan tersebut antara lain:

1. Tingkat pendidikan

Berdasarkan persepsi responden bahwa latar belakang pendidikan staf perencana di SKPD belum sepenuhnya memiliki kualifikasi yang tepat sesuai dengan basic keilmuan yang dimiliki. Latar belakang pendidikan tersebut menjadi faktor utama kenapa indikator ini berada pada kategori kurang baik. Bahkan ada beberapa SKPD yang tidak memiliki latar belakang pendidikan yang tidak tepat, tetapi beberapa ada yang tidak sesuai dengan tingkat pendidikan yang dimilikinya yaitu DIII. Selain itu dikarenakan adanya kekurangan personil yang memiliki kualifikasi yang mencukupi tersebut, ada beberapa SKPD yang menugaskan satu personil untuk melaksanakan beberapa fungsi yang berbeda.

2. Kesempatan pelatihan

Pelatihan menjadi salah satu upaya untuk meningkatkan kompetensi SDM khususnya pada bagian perencanaan dan penganggaran ini. Akan tetapi kesempatan tersebut terbilang cukup langka untuk didapatkan. Hal tersebut dikarenakan kondisi keuangan daerah yang tidak stabil dan cenderung mengalami penurunan setiap tahunnya yang mengakibatkan harus terjadinya efisiensi angaran setiap tahunnya. Ploting anggaran yang sering mendapatkan revisi adalah anggaran kegiatan pelatihan yang diusulkan oleh SKPD. Hal tersebut menjadikan responden hanya dapat mengandalkan kesempatan pelatihan yang merupakan kegiatan yang dilaksanakan oleh angaran yang bersumber dari selain APBD Kabupaten Kepulauan Anambas.

3. Biaya Pengembangan

Keterbatasan anggaran yang dialami oleh Pemerintah Daerah Kabupaten Kepulauan Anambas memberikan dampak terhadap pelaksanaan kegiatan pengembangan 
kapasitas SDM. Menurut responden, hal ini berkorelasi dengan kesempatan pelatihan yang dimiliki oleh personil perencanaan untuk dapat melakukan pengembangan kompetensi diri.

4. Pelatihan

Indikator ini menunjukkan bahwa personil perencana dan penganggaran masih belum mendapatkan pelatihan yang cukup atau bahkan belum pernah mendapat kesempatan pelatihan perencanaan dan penganggaran secara khusus.

5. Sertifikasi

Secara umum, pejabat Eselon telah mengikuti pelatihan sehingga mendapatkan sertifikasi terkait perencanaan dan penganggaran. Walaupun tetap saja ada beberapa pejabar eselon yang juga belum mendapatkannya. Menurut responden, hal tersebut menjelaskan bahwa masih banyak juga staf perencana yang belum mendapatkan sertifikasi mengenai perencanaan dan anggaran

\section{Komponen Sistem Administrasi Perencanaan dan Penganggaran}

Berdasarkan pengukuran yang dilakukan, diketahui bahwa indikator yang ada pada komponen sistem administrasi perencanaan dan penganggaran berada pada kategori tinggi dengan perolehan skor 191. Adapun yang menjadi perhatian adalah terkait penerapan ASB.

Menurut responden, dengan adanya dinamika kebijakan yang mengatur tentang pengelolaan keuangan mengharuskan pemerintah khususnya pemerintah daerah untuk dapat terus berkembang dan menyesuaikan dengan kemajuan yang ada. ASB merupakan salah satu terobosan baru dengan harapan untuk menghasilkan perencanaan dan penanggaran yang lebih akuntabel. Namun hal tersebut masih belum dapat dilaksanakan secara maksimal, khususnya daerah. Oleh karena itu daerah masih mendapatkan toleransi khususnya dalam penerapan kebijakan-kebijakan baru salah satunya adalah penggunaan ASB. Walaupun demikian, Kabupaten Kepulauan Anambas telah mulai melakukan penyesuaian secara bertahap untuk menerapkan ASB melalui beberapa SKPD yang akan menjadi projek percontohan bagi SKPD lainnya.

\section{Komponen Kesesuaian Perencanaan dan Penganggaran}

Hasil pengolahan data kuesioner yang dilakukan pada komponen kesesuaian perencanaan dan penganggaran berada pada kategori Tinggi dengan perolehan skor 328 . Namun dari semua indikator yang diukur, terdapat satu indikator yang masih berada pada kategori kurang baik. Indikator tersebut adalah manfaat program. Berdasarkan wawancara yang dilakukan, responden mengatakan bahwa pelaksanaan belum sepenuhnya dirasakan oleh penerima manfaat. Walaupun sebagian besar mendapatkan respon yang positif, tetapi tentu saja masih terdapat kekurang yang muncul. Salah satunya contohnya adalah tidak tepatnya metode pengelolaan program subsektor kelautan perikanan yang dilakukan. Hal tersebut menjadi evaluasi dan catatan khusus untuk proses perencanaan kegiatan yang memiliki karakteristik yang serupa.

\section{Komponen Penghargaan (Reward)}

Hasil pengolahan data kuesioner menunjukkan perolehan skor toral 144 dengan persentase 80 persen. Hal ini menunjukkan bahwa penghargaan menjadi motivasi dalam meningkatkan kinerja aparatur sipil negara khususnya aparatur pelaksana perencanaan dan penganggaran. Hal tersebut menjadi target tersediri bagi aparatur sehingga dapat menghasilkan prestasi kerja yang baik. Reward yang diberikan dapat berupa promosi jabatan maupun insentif, 
sementara untuk instansi terkait yang berhasil mencapai target dapat berupa penghargaan maupun sertifikat.

\section{Komponen Sanksi (punishment)}

Komponen yang kelima dalam implementasi perencanaan dan penganggaran pada subsektor kelautan dan perikanan di Kabupaten Kepulauan Anambas adalah sanksi. Komponen ini memperlihatkan apakah pemberian sanksi dapat menjadi warning maupun dorongan bagi SKPD agar dapat bekerja secara maksimal agar dapat mencapai target yang tentukan. Berdasarkan pengukuran yang dilakukan, komponen sanksi memperoleh skor toral 137 dengan persentase 76,11. Nilai maksimal yang dapat diperoleh pada komponen ini adalah 180 dan nilai minimal yang dapat diperoleh adalah 45 . Berdasarkan skor yang diperoleh maka komponen sanksi berada pada kategori baik.

Hasil tersebut menunjukkan bahwa setiap indikator yang diukur memperoleh kategori yang baik. Hal tersebut menggambarkan bahwa pemberian sanksi juga merupakan salah satu langkah untuk dapat memberikan dorongan kepada aparatur prencanaan dan penganggaran untuk dapat menghasilkan perencanaan dan penganggaran yang baik serta dapat dilaksanakan dan berdampak positif khususnya pada subsektor kelautan dan perikanan. Berdasarkan wawancara responden, penerapan sanksi sudah sewajarnya untuk dilaksanakan. Sanksi tersebut selayaknya diberikan kepada personal yang melakukan kelalaian, bukan kepada instansi terkait. Sehingga memberikan dampak khusus kepada penerima, serta menjadi contoh bagi yang lain dan tidak menggangu keberlanjutan program maupun kegiatan yang telah direncanakan.

\section{Strategi Penguatan Perencanaan dan Penganggaran Pada Subsektor Kelautan dan Perikanan di Kabupaten Kepulauan Anambas}

Berdasarkan hasil wawancara yang dilakukan dan kajian terhadap dokumen terkait, diperoleh 19 (sembilan belas) faktor strategis yang berperan dalam penguatan perencanaan dan penganggaran pada subsektor kelautan dan perikanan di Kabupaten Kepulauan Anambas. Langkah selanjutnya adalah memberikan kuesioner kepada informan untuk melakukan penilaian atas faktor internal dan eksternal. Hasil penilaian atas faktor internal dan eksternal menggunakan Internal Factor Evaluation (IFE) dan External Factor Evaluation (EFE) disajikan dalam Tabel 4 dan Tabel 5 .

Tabel 4 Analisis IFE penguatan perencanaan dan penganggaran pada subsektor kelautan dan perikanan di Kabupaten Kepulauan Anambas

\begin{tabular}{rlccc}
\hline & \multicolumn{1}{c}{ Faktor Strategis Internal } & Bobot & Rating & Skor \\
\hline No. & \multicolumn{1}{c}{ Kekuatan/ strength $(\mathrm{S})$} & & & \\
\hline S1 & $\begin{array}{l}\text { Komitmen Kepala Daerah dalam mendukung perencanaan } \\
\text { penganggaran berdasarkan visi daerah }\end{array}$ & 0,117 & 4,00 & 0,467 \\
S2 & Struktur organisasi dan tupoksi SKPD yang jelas & 0,109 & 3,00 & 0,328 \\
S3 & Ketersediaan SDM muda yang potensial & 0,096 & 3,67 & 0,353 \\
S4 & Target pembangunan yang tercantum jelas pada RPJM & 0,100 & 3,67 & 0,367 \\
S5 & $\begin{array}{l}\text { Peran Tim Anggaran Pemerintah Daerah (TAPD) dan } \\
\text { Dewan Perwakilan Rakyat Daerah (DPRD) dalam } \\
\text { perencanaan penganggaran yang aktif }\end{array}$ & 0,093 & 3,33 & 0,309 \\
& Total & 0,515 & & 1,823
\end{tabular}




\begin{tabular}{rlrrr}
\hline \multicolumn{1}{l}{ Lanjutan Tabel 4} & & & \\
\hline No. & \multicolumn{1}{c}{ Kelemahan/weakness $(\mathrm{W})$} & & \\
\hline W1 & $\begin{array}{l}\text { Rendahnya Leadership OPD dalam mewujudkan target } \\
\text { RPJM }\end{array}$ & 0,106 & 1,67 & 0,176 \\
W2 & $\begin{array}{l}\text { Pembagian tupoksi internal OPD yang masih belum jelas } \\
\text { W3 }\end{array}$ & 0,102 & 1,33 & 0,136 \\
Kualitas dan kuantitas aparatur perencanaan di SKPD masih & 0,094 & 2,00 & 0,189 \\
W4 $\begin{array}{l}\text { Rotasi/mutasi pegawai yang sering terjadi dan tidak } \\
\text { diimbangi dengan kesesuaian kecakapan }\end{array}$ & 0,096 & 2,00 & 0,193 \\
W5 $\begin{array}{l}\text { Pengembangan SDM aparatur perencanaan oleh Pemerintah } \\
\text { Daerah masih kurang memadai }\end{array}$ & 0,087 & 1,67 & 0,145 \\
\hline & Total & 0,485 & 1,000 & 0,838 \\
\hline
\end{tabular}

Hasil penghitungan Internal Factor Evaluation (IFE) menunjukkan bahwa pada faktor strategis internal, pada kekuatan, menjelaskan bahwa kepaladaerah mendukung segala upaya yang diperlukan untuk dapat melaksanakan perencanaan dan penganggaran yang selaras dengan visi daerah. Sementara yang terlihat pada kelemahan adalah dalam pelaksanaan perencanaan dan penganggaran sering terjadi mutasi/rotasi pegawai. Hal tersebut tentunya sangat menghambat proses prencanaan dan penganggaran karena aparatur perencana akan harus kembali mengulang dan beradaptasi kembali terhadap kondisi kerja yang baru.

Tabel 5 Analisis EFE penguatan perencanaan dan penganggaran pada subsektor kelautan dan perikanan di Kabupaten Kepulauan Anambas

\begin{tabular}{|c|c|c|c|c|}
\hline & Faktor Strategis Eksternal & Bobot & Rating & Skor \\
\hline \multicolumn{5}{|c|}{ Peluang/Opportunities $(\mathrm{O})$} \\
\hline $\mathrm{O} 1$ & $\begin{array}{l}\text { Regulasi Pemerintah tentang sistem perencanaan } \\
\text { dan penganggaran yang jelas }\end{array}$ & 0,111 & 2,67 & 0,296 \\
\hline $\mathrm{O} 2$ & $\begin{array}{l}\text { Regulasi Pemerintah tentang perjanjian kinerja } \\
\text { dan tatacara reviu atas laporan kinerja instansi } \\
\text { pemerintahan }\end{array}$ & 0,100 & 2,33 & 0,232 \\
\hline $\mathrm{O} 3$ & $\begin{array}{l}\text { Kebijakan Pemerintah Pusat terkait pembangunan } \\
\text { sektor maritim }\end{array}$ & 0,130 & 3,67 & 0,475 \\
\hline $\mathrm{O} 4$ & $\begin{array}{l}\text { Komitmen Pemerintah Provinsi dalam mendukung } \\
\text { pengembangan sektor kelautan perikanan }\end{array}$ & 0,130 & 3,33 & 0,432 \\
\hline \multirow[t]{2}{*}{ O5 } & $\begin{array}{l}\text { Diklat khusus bidang perencanaan oleh } \\
\text { kementerian yang bekerjasama dengan } \\
\text { institusi/perguruan tinggi }\end{array}$ & 0,109 & 2,33 & 0,254 \\
\hline & Total & 0,579 & & 1,690 \\
\hline
\end{tabular}


Lanjutan Tabel 5

\begin{tabular}{clccc}
\hline No. & \multicolumn{1}{c}{ Ancaman/Thread (T) } & & \\
\hline T1 & $\begin{array}{l}\text { Ketidakpastian (fluktuasi) dana transfer pusat } \\
\text { untuk daerah }\end{array}$ & 0,093 & 4,00 & 0,370 \\
T2 & $\begin{array}{l}\text { Keterlambatan informasi alokasi dana transfer } \\
\text { pusat untuk daerah }\end{array}$ & 0,109 & 3,67 & 0,399 \\
T3 & $\begin{array}{l}\text { Ketidakpastian keberlanjutan program subsektor } \\
\text { kelautan dan perikanan oleh Pemerintah Pusat }\end{array}$ & 0,111 & 3,00 & 0,333 \\
& $\begin{array}{l}\text { Belum adanya evaluasi khusus terhadap } \\
\text { perencanaan penganggaran subsektor kelautan dan } \\
\text { perikanan }\end{array}$ & 0,109 & 2,33 & 0,254 \\
& Total & 0,421 & & 1,356 \\
\hline & Total EFE & 1,000 & 3,046 \\
\hline
\end{tabular}

Hasil penghitungan yang dilakukan pada faktor strategis eksternal menunjukkan bahwa, peluang dengan skor tertinggi yang menandakan adanya kesempatan yang dapat diraih adalah adanya kebijakan pemerintah pusat terkait pembangunan sektor maritim. Melalui kebijakan tersebut, diharapkan mampu mensinergikan pemerintah pusat dengan pemerintah daerah sehingga menghasilkan akselerasi pembangunan. Sementara ancaman dengan skor tertinggi adalah keterlambatan informasi alokasi dana transfer pusat untuk daerah. Hal tersebut tersebut tentunya sangat mempengaruhi kondisi keuangan daerah yang disebabkan masih sangat tergantung kepada dana perimbangan oleh pusat untuk daerah

\begin{tabular}{|c|c|c|c|c|}
\hline \multicolumn{4}{|c|}{ Skor Total IFE 2,661 } & \multirow{9}{*}{$\begin{array}{c}\text { 3,046 } \\
\text { Skor Total } \\
\text { EFE }\end{array}$} \\
\hline & Kuat & Sedang & Lemah & \\
\hline & $3.00-4.00$ & $2.00-2.99$ & $1.00-1.99$ & \\
\hline Tinggi & $\mathrm{I}$ & II & III & \\
\hline $3.00-4.00$ & $\begin{array}{c}\text { Grow and } \\
\text { Build }\end{array}$ & $\begin{array}{l}\text { Grow and } \\
\text { Build }\end{array}$ & $\begin{array}{l}\text { Hold and } \\
\text { Maintain }\end{array}$ & \\
\hline Sedang & IV & V & VI & \\
\hline $2.00-2.99$ & $\begin{array}{c}\text { Grow and } \\
\text { Build }\end{array}$ & $\begin{array}{l}\text { Hold and } \\
\text { Maintain }\end{array}$ & $\begin{array}{c}\text { Harvest and } \\
\text { Divestiture }\end{array}$ & \\
\hline Rendah & VII & VIII & IX & \\
\hline $1.00-1.99$ & $\begin{array}{l}\text { Hold and } \\
\text { Maintain }\end{array}$ & $\begin{array}{c}\text { Harvest and } \\
\text { Divestiture }\end{array}$ & $\begin{array}{c}\text { Harvest and } \\
\text { Divestiture }\end{array}$ & \\
\hline
\end{tabular}

\section{Perumusan Alternatif Strategi}

Berdasarkan hasil yang diperoleh pada Tabel 4 dan Tabel 5 menunjukkan bahwa hasil analisis internal dan eksternal yang mempengaruhi perencanaan dan penganggaran pada subsektor kelautan dan perikanan di Kabupaten Kepulauan Anambas masing- memperoleh skor IFE = 2,661 dan EFE 3,046. Nilai tersebut akan digunakan untuk membentuk matrik Internal Eksternal (IE) untuk kemudian menjadi panduan dalam menentukan pendekatan pembangunan yang tepat sesuai dengan faktor-faktor yang telah dianalisis. Matrik tersebut disajikan pada Gambar 1.

\section{Gambar 1 Matriks IE perencanaan dan penganggaran pada subsektor kelautan dan perikanan di Kabupaten Kepulauan Anambas}


Matrik IE pada Gambar 1 menunjukkan bahwa strategi yang tepat adalah dengan menggunakan pendekatan tumbuh dan membangun (growth and build). Strategi-strategi yang cocok adalah strategi yang intensif dan terintegrasi untuk penguatan perencanaan dan penganggaran pada subsektor kelautan dan perikanan di Kabupaten Kepulauan Anambas Rumusan alternatif strategi yang sesuai yang dapat dilakukan sebagai tersaji pada Tabel 6

Tabel 6 Matriks SWOT dan alternatif strategi dalam penguatan perencanaan dan penganggaran pada subsektor kelautan dan perikanan di Kabupaten Kepulauan Anambas

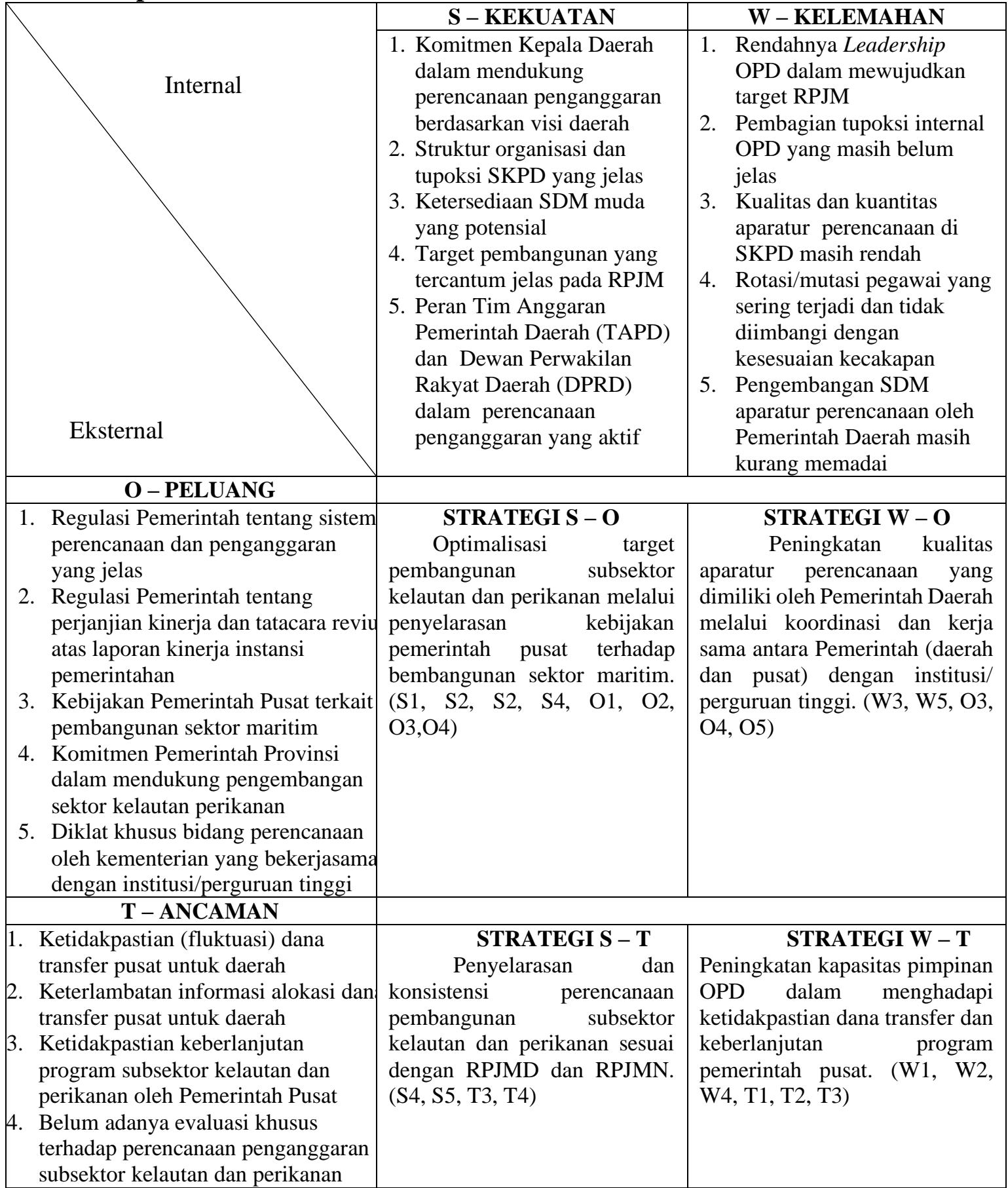




\section{Perumusan Strategi Prioritas}

Penggunaan QSPM bertujuan untuk memperoleh strategi yang menjadi prioritas terbaik dan yang paling menarik untuk diimplementasikan sesuai dengan arah dan kebijakan Pemerintah Kabupaten Kepulauan Anambas dalam rangka penguatan perencanaan dan penganggaran pada subsektor kelautan dan perikanan. Penentuan prioritas strategi dilakukan dengan cara menentukan rating atau tingkat ketertarikan relatif (relative attractiveness) dari strategi-strategi yang telah dipilih. Skor yang diberikan untuk daya tarik terbagi atas empat pilihan, yaitu 1 untuk tidak menarik, 2 untuk agak menarik, 3, cukup menarik dan 4 untuk sangat menarik. Skor yang diberikan tersebut akan menghasilkan skor daya tarik total (Total Attractiveness Score$T A S)$. Skor tersebut akan dijumlahkan sehingga akan mendapat nilai total TAS dari masing-masing strategi. Skor yang paling tinggi menandakan bahwa strategi tersebut paling menarik dan lebih di utamakan untuk diimplementasikan.

Penentuan strategi dan pemberian skor tersebut diperlukan ketelitian, intuisi serta pengalaman yang mumpuni. Karena hal tersebut, maka kuesioner QSPM ini hanya diberikan kepada pemegang kebijakan yang memiliki kewenangan. Hasil dari penilaian terebut disajikan secara ringkas pada Tabel 7.

Tabel 7 Prioritas strategi perencanaan dan penganggaran pada subsektor kelautan dan perikanan

\begin{tabular}{clcc}
\hline No & \multicolumn{1}{c}{ Strategi } & TAS & Peringkat \\
\hline 1 & $\begin{array}{l}\text { Optimalisasi target pembangunan subsektor kelautan dan } \\
\text { perikanan melalui penyelarasan kebijakan pemerintah pusat } \\
\text { terhadap bembangunan sektor maritim. }\end{array}$ & 5,546 & 3 \\
2 & $\begin{array}{l}\text { Peningkatan kualitas aparatur perencanaan yang dimiliki oleh } \\
\text { Pemerintah Daerah melalui koordinasi dan kerja sama antara }\end{array}$ & 6,107 & 1 \\
3 & $\begin{array}{l}\text { Pemerintah (daerah dan pusat) dengan institusi/perguruan tinggi } \\
\text { Penyelarasan dan konsistensi perencanaan pembangunan } \\
\text { subsektor kelautan dan perikanan sesuai dengan RPJMD dan } \\
\text { RPJMN. }\end{array}$ & 5,300 & 4 \\
\hline & $\begin{array}{l}\text { Peningkatan kapasitas pimpinan OPD dalam menghadapi } \\
\text { ketidakpastian dana transfer dan keberlanjutan program } \\
\text { pemerintah pusat. }\end{array}$ & 5,691 & 2 \\
\hline
\end{tabular}

Berdasarkan penghitungan yang dilakukan atas penilaian yang diberikan oleh responden terhadap skor daya tarik dari setiap strategi terhadap faktor-faktor yang berpengaruh dengan menggunakan kuesioner QSPM pada Tabel 7, maka diperoleh hasil bahwa skor tertinggi adalah 6,107. Strategi yang memperoleh nilai TAS tersebut merupakan strategi kedua, yaitu strategi yang menggunakan pendekatan W-O. Artinya adalah strategi yang layak untuk mendapatkan prioritas adalah strategi peningkatan kualitas aparatur perencanaan yang dimilki oleh Pemerintah Daerah melalui koordinasi dan kerja sama antara Pemerintah (daerah dan pusat) dengan institusi/perguruan tinggi. Hasil sejalan dengan analisis pada tujuan pertama dan kedua dari penelitian ini. Hasil ini membuktikan bahwa untuk menghasilkan perencanaan dan penganggaran pada subsektor kelautan dan perikanan yang konsisten juga memerlukan kompetensi SDM perencanaan dan penganggaran yang baik pula.

\section{Perencanaan Implementasi Strategi}


Menindaklanjuti hasil strategi utama yang telah diperoleh berdasarkan analisis QSPM yang dilakukan adalah dengan merealisasikan strategi tersebut. Agar dapat dilaksanakan tentunya strategi memerlukan penjabaran yang baik sehingga dapat menjadi pedoman pelaksanaan yang tepat sesuai dengan tujuan strategi tersebut. Penjabaran strategi tersebut tertuang melalui kebijakan operasional. Kebijakan tersebut akan dilaksanakan melalui program dan kegiatan seperti yang akan disajikan pada Tabel 8.

Tabel 8 Implementasi strategi penguatan perencanaan dan penganggaran pada subsektor kelautan dan perikanan di Kabupaten Kepulauan Anambas.

\begin{tabular}{|c|c|c|c|c|c|}
\hline Strategi & Program & Kegiatan & Output & $\begin{array}{c}\text { Penanggung } \\
\text { jawab }\end{array}$ & $\begin{array}{c}\text { Waktu } \\
\text { Pelaksanaa } \\
\text { n }\end{array}$ \\
\hline \multirow{4}{*}{$\begin{array}{l}\text { Peningkatan } \\
\text { kualitas aparatur } \\
\text { perencanaan yang } \\
\text { dimiliki oleh } \\
\text { Pemerintah Daerah } \\
\text { melalui koordinasi } \\
\text { dan kerja sama } \\
\text { antara Pemerintah } \\
\text { (daerah dan pusat) } \\
\text { dengan } \\
\text { institusi/perguruan } \\
\text { tinggi }\end{array}$} & $\begin{array}{l}\text { Pembinaan } \\
\text { dan } \\
\text { pengembanga } \\
\text { n sumber saya } \\
\text { aparatur }\end{array}$ & $\begin{array}{l}\text { Seleksi } \\
\text { penerimaan } \\
\text { CPNS } \\
\text { fungsional } \\
\text { perencana di } \\
\text { OPD } \\
\text { Kabupaten } \\
\text { Kepulauan } \\
\text { Anambas }\end{array}$ & $\begin{array}{l}\text { Tersedianya } \\
\text { formasi } \\
\text { aparatur } \\
\text { perencanaan } \\
\text { dan } \\
\text { penganggaran } \\
\text { yang sesuai } \\
\text { dengan } \\
\text { kompetensinya }\end{array}$ & $\begin{array}{l}\text { Badan } \\
\text { Kepegawaian } \\
\text { dan } \\
\text { Pengembanga } \\
\text { n Sumber } \\
\text { Daya Manusia } \\
\text { Bidang } \\
\text { Pengembanga } \\
\text { n SDM }\end{array}$ & $2018-2019$ \\
\hline & $\begin{array}{l}\text { Pembinaan } \\
\text { dan } \\
\text { pengembangan } \\
\text { Kapasitas } \\
\text { sumber saya } \\
\text { aparatur } \\
\text { perencanaan } \\
\text { dan } \\
\text { penganggaran }\end{array}$ & $\begin{array}{l}\text { Open } \\
\text { bidding } \\
\text { jabatan } \\
\text { fungsional } \\
\text { perencana } \\
\text { tingkat } \\
\text { pertama, } \\
\text { muda dan } \\
\text { madya } \\
\end{array}$ & $\begin{array}{l}\text { tersedianya } \\
\text { fungsional } \\
\text { perencana } \\
\text { tingkat } \\
\text { pertama, muda } \\
\text { dan madya } \\
\text { yang } \\
\text { kompeten dan } \\
\text { berdedikasi }\end{array}$ & $\begin{array}{l}\text { Sekretaris } \\
\text { Daerah, Badan } \\
\text { Kepegawaian } \\
\text { dan } \\
\text { Pengembanga } \\
\text { n Sumber } \\
\text { Daya Manusia, } \\
\text { Baperjakat }\end{array}$ & $2018-2019$ \\
\hline & & $\begin{array}{l}\text { Bimbingan } \\
\text { teknis } \\
\text { perencanaan } \\
\text { dan } \\
\text { penganggara } \\
\text { n yang } \\
\text { terpadu dan } \\
\text { perkelanjutan }\end{array}$ & $\begin{array}{l}\text { Meningkatnya } \\
\text { pemahaman } \\
\text { terhadap } \\
\text { perencanaan } \\
\text { yang terpadu } \\
\text { dan } \\
\text { berkelanjutan }\end{array}$ & $\begin{array}{l}\text { Pemerintah } \\
\text { daerah, } \\
\text { BAPPENAS, } \\
\text { Institusi } \\
\text { Pendidikan }\end{array}$ & $2019-2021$ \\
\hline & & $\begin{array}{l}\text { Pendidikan } \\
\text { dan pelatihan } \\
\text { jabatan } \\
\text { fungsional } \\
\text { perencana } \\
\text { OPD } \\
\text { Kabupaten } \\
\text { Kepulauan } \\
\text { Anambas }\end{array}$ & $\begin{array}{l}\text { Meningkatnya } \\
\text { pemahaman } \\
\text { dan } \\
\text { kompetensi } \\
\text { pejabat } \\
\text { fungsional } \\
\text { perencana }\end{array}$ & $\begin{array}{l}\text { Pemerintah } \\
\text { daerah, } \\
\text { BAPPENAS, } \\
\text { Institusi } \\
\text { Pendidikan }\end{array}$ & $2019-2020$ \\
\hline
\end{tabular}


Berdasarkan strategi utama yang telah dirumuskan melalui program pembinaan dan pengembangan sumber daya aparatur serta program Pembinaan dan pengembangan Kapasitas sumber saya aparatur perencanaan dan penganggaran memiliki beberapa kegiatan sebagaimana yang disajikan pada Tabel 8. Adapun kegiatan tersebut meliputi:

1. Seleksi penerimaan CPNS fungsional perencana di OPD Kabupaten Kepulauan Anambas

Terbatasnya aparatur perencana baik secara kuantitas maupun kualitas menjadi alasan diperlukannya penerimaan CPNS fungsional baru, dengan bertambahnya khususnya yang memiliki latar belakang perencanaan dan penganggaran. Sehingga diharapkan mampu menghasilkan perencanaan dan penganggaran yang berkualitas.

2. Open bidding jabatan fungsional perencana tingkat pertama, muda dan madya

Open bidding diharapkan menjadi terobosan baru untuk menghasilkan pejabat eselon maupun fungsional yang memiliki dedikasi dan kualifikasi yang tinggi terhadap jabatan yang akan diamanahkan. Pelaksanaan open bidding diharapkan juga mampu menjadi instrumen untuk menilai kelayakan dan kemampuan pejabat eselon maupun fungsional untuk mendapatkan keempatan pengembangan karir yang lebih baik.

3. Pendidikan dan pelatihan jabatan fungsional perencana OPD Kabupaten Kepulauan Anambas

Sebagai pejabat fungsional yang khusus menangani bagian perencanaan dan penganggaran sudah selayaknya untuk mendapatkan pelatihan khusus agar dapat memberikan kontribusi sesuai dengan jabatannya serta mampu menciptakan lingkungan yang positif khususnya pada bagian perencanaan agar menghasilkan perencanaan dan penganggaran yang akuntable.
4. Bimbingan teknis perencanaan dan penganggaran yang terpadu dan berkelanjutan

Tidak hanya kepada pejabat fungsional, aparatur pelaksana yang terlibat pada proses perencanaan dan penganggaran sudah selayaknya mendapatkan pengembangan kapasitas diri. Kegiatan ini dilaksanakan dengan bekerja sama antara Pemerintah Pusat dalam hal ini Badan Perencanaan Nasional serta Institusi Perguruan tinggi sebagai wujud transfer knowledge yang baik demi terwujudnya pemerintahan yang baik.

\section{SIMPULAN DAN SARAN}

\section{Simpulan}

1. Proses perencanaan dan penganggaran pada subsektor kelautan dan perikanan di Kabupaten tersebut masih terjadi inkonsistensi. Inkonsistensi dan penganggaran pada subsektor kelautan dan perikanan di Kabupaten Kepulauan Anambas terjadi baik pada kegiatan maupun deviasi anggaran.

2. Tingkat implementasi perencanaan Kepulauan Anambas adalah baik dengan catatan komponen kompetensi SDM perencanaan dan penganggaran masih kurang baik sehingga masih perlu perbaikan.

3. Strategi yang dilaksanakan terkait penguatan perencanaan dan penganggaran pada subsektor kelautan dan perikanan di Kabupaten Kepulauan Anambas adalah melalui peningkatan kualitas aparatur perencanaan yang dimiliki oleh Pemerintah Daerah melalui koordinasi dan kerja sama antara Pemerintah (daerah dan pusat) dengan institusi/perguruan tinggi.

\section{Saran}

1. Melaksanakan pelatihan dan bimbingan teknis khususnya dalam 
meningkatkan kompetensi aparatur perencanaan dan penganggaran

2. Melaksanakan strategi penguatan perencanaan dan penganggaran pada subsektor kelautan dan perikanan di Kabupaten Kepulauan Anambas yang telah dirumuskan dalam penelitian ini.

3. Melakukan koordinasi lebih lanjut kepada pemerintah pusat terkait alokasi dana transfer daerah untuk menjaga kestabilan dan kebersinambungan perencanaan dan penganggaran.

\section{DAFTAR PUSTAKA}

Adisasmita R. 2011. Pengelolaan Pendapatan dan Anggaran Daerah. Yogyakarta (ID): Graha Ilmu.

Bastian I. 2006b. Sistem Perencanaan dan Penganggaran Pemerintah Daerah di Indonesia. Jakarta (ID): Salemba Empat.

[BPS KKA] Badan Pusat dan Statistika Kabupaten Kepulauan Anambas. 2016. Kabupaten Kepulauan Anambas Dalam Angka 2016. Anambas (ID): BPS.

David FR, David FR. 2015. Manajemen Strategik: Suatu Pendekatan Keunggulan Bersaing. Jakarta (ID): Salemba Empat.

Domai T. 2013. Manajemen Keuangan Publik. Malang (ID): UB Press.

Kinnear TC, Taylor JR. 1991. Riset

Pemasaran Jilid 1. Jakarta (ID): Erlangga 